\title{
Correction to: The effectiveness of marine based fatty acid compound (PCSO-524) and firocoxib in the treatment of canine osteoarthritis
}

\author{
Monchanok Vijarnsorn', Irin Kwananocha', Narudee Kashemsant ${ }^{2}$, Thitichai Jarudecha', \\ Chalermpol Lekcharoensuk ${ }^{1}$, Brian Beale ${ }^{3}$, Bruno Peirone ${ }^{4}$ and B. Duncan X. Lascelles ${ }^{5,6,7^{*}}$
}

\section{Correction to: BMC Vet Res 15, 349 (2019) \\ https://doi.org/10.1186/s12917-019-2110-7}

The original article [1] omitted competing interests which can be viewed ahead.

\section{Competing interests}

BDXL has provided, and been renumerated for, continuing educational lectures sponsored by Pharmalink International, including reimbursement of travel expenses. $\mathrm{BB}$ has provided, and been renumerated for, continuing educational lectures, appeared in marketing materials and has received research funds and travel expenses from Pharmalink International. The other authors have no other conflicts of interest to declare.

\section{Author details}

${ }^{1}$ Department of Companion Animals Clinical Sciences. Faculty of Veterinary Medicine, Kasetsart University, Bangkok 10900, Thailand. ²Department of Physiology, Faculty of Veterinary Medicine, Kasetsart University, Bangkok 10900, Thailand. ${ }^{3}$ Gulf Coast Veterinary Specialists, Houston, TX, USA. ${ }^{4}$ Dipartimento di Scienze Veterinarie, Facoltà di Medicina Veterinaria, Largo, P. Braccini, 2-5, 10095 Grugliasco (To), Italy. ${ }^{5}$ Translational Research in Pain Program, Comparative Pain Research and Education Centre, Department of Clinical Sciences, College of Veterinary Medicine, North Carolina State University, Raleigh, NC, USA. ${ }^{6}$ Center for Translational Pain Research,

The original article can be found online at https://doi.org/10.1186/s12917019-2110-7

* Correspondence: dxlascel@ncsu.edu

${ }^{5}$ Translational Research in Pain Program, Comparative Pain Research and Education Centre, Department of Clinical Sciences, College of Veterinary Medicine, North Carolina State University, Raleigh, NC, USA

${ }^{6}$ Center for Translational Pain Research, Department of Anesthesiology, Duke University, Durham, NC, USA

Full list of author information is available at the end of the article
Department of Anesthesiology, Duke University, Durham, NC, USA. ${ }^{7}$ Thurston Arthritis Center, UNC, Chapel Hill, NC, USA.

Published online: 16 December 2020

Reference

1. Vijarnsorm $\mathrm{M}$, et al. The effectiveness of marine based fatty acid compound (PCSO-524) and firocoxib in the treatment of canine osteoarthritis. BMC Vet Res. 2020;15:349. https://doi.org/10.1186/s12917-019-2110-7.

(c) The Author(s). 2020 Open Access This article is licensed under a Creative Commons Attribution 4.0 International License, which permits use, sharing, adaptation, distribution and reproduction in any medium or format, as long as you give appropriate credit to the original author(s) and the source, provide a link to the Creative Commons licence, and indicate if changes were made. The images or other third party material in this article are included in the article's Creative Commons licence, unless indicated otherwise in a credit line to the material. If material is not included in the article's Creative Commons licence and your intended use is not permitted by statutory regulation or exceeds the permitted use, you will need to obtain permission directly from the copyright holder. To view a copy of this licence, visit http://creativecommons.org/licenses/by/4.0/ The Creative Commons Public Domain Dedication waiver (http://creativecommons.org/publicdomain/zero/1.0/) applies to the data made available in this article, unless otherwise stated in a credit line to the data. 